\title{
Assessment of the profitability and the effects of three maize-based cropping systems on soil health in Western Africa
}

\author{
Kodjovi Sotomè Detchinli, Jean Mianikpo Sogbedji \\ Ecole Supérieure d'Agronomie, Université de Lomé, Lomé, Togo
}

Email address:

skdetch@gmail.com (K. S. Detchinli), mianikpo@yahoo.com (J. M. Sogbedji)

To cite this article:

Kodjovi Sotomè Detchinli, Jean Mianikpo Sogbedji. Assessment of the Profitability and the Effects of Three Maize-Based Cropping Systems on Soil Health in Western Africa. American Journal of Agriculture and Forestry. Vol. 2, No. 6, 2014, pp. 321-329.

doi: 10.11648/j.ajaf.20140206.25

\begin{abstract}
Enhanced livelihoods for populations, especially smallholder farmers in sub-Saharan Africa may be achieved through improved cropping systems. We assessed the economic returns from maize grain yield and the effects of three cropping systems on soil properties in an eight-year study segmented in cycles of two years each: continuous maize (Zea mays L.), maize-mucuna (Mucuna pruriens var. utilis), and maize-pigeon pea (Cajanus cajan). The rainfall pattern in the study region allows for two growing seasons per year, leading to four growing seasons per cycle. Nitrogen (N) and phosphorus $(\mathrm{P})$ fertilizer rates were imposed on maize in each system and maize grain yields and associated cash values as well as soil properties were measured. Seeding mucuna and pigeon pea crops into maize crop in the first year did not result in maize grain yield increases from $\mathrm{N}$ and $\mathrm{P}$ fertilizers in the subsequent year. Continuous maize system increased mean maize grain yields by 6.2 to $60.3 \%$ in the fallow year of the 2002-2003 and 2006-2007 cycles and by 5.1 to $8.2 \%$ on a cycle basis in the $2002-2003$ cycles. For the remaining periods of the study, mucuna and pigeon pea based maize cropping increased grain yields by 28.6 to $47.6 \%, 22$ to $260 \%$ and 28.3 to $136.1 \%$ in fallow year, non-fallow years and on a cycle basis, respectively, compared to yields under continuous maize. On a cycle basis, economic returns for maize-mucuna and maize-pigeon pea based systems were 105.1 and $66.5 \%$, respectively, higher than that for continuous maize. The mucuna and pigeon pea based systems increased the initial soil total carbon (C) content by 55 and 69\%, respectively, resulted in increases of 110 to $117 \%, 33$ to $63 \%$, 29\%, and 16 $17 \%$ for exchangeable $\mathrm{Ca}^{2+}, \mathrm{Mg}^{2+}, \mathrm{K}^{+}$and total cation exchange capacity (CEC), respectively, and enhanced water stable macroaggregates stability, compared to continuous maize. Maize mucuna and pigeon pea-based maize cropping systems with mucuna and pigeon crops in alternate years should be advised towards sustaining enhanced profitability and improved soil physical and chemical properties.
\end{abstract}

Keywords: Maize, Mucuna, Pigeon Pea, Fertilizer, Soil Properties, Profitability

\section{Introduction}

There is still an increasingly growing concern about the issue of food shortages in Africa which has become a major obstacle to the development of the continent, especially the sub-Saharan region. During the last three decades the region has experienced a population growth of $3.1 \%$ against a $2.1 \%$ food production growth rate [1]. Therefore, a major challenge for scientists, governments and other stakeholders in the region is that food production should increase by $70 \%$ by 2050 to meet the necessary caloric requirements [2]. The agricultural intensification is recognized as the main opportunity to meet rising food needs [3]. In Sub-Saharan
Africa (SSA), smallholder farmers have experienced declining yields, increasing costs of production and growing uncertainty of producing the food needed by their families. Major factors contributing to such uncertainty and decline in productivity are: soil degradation, dry spells, erratic availability of inputs particularly mineral fertilizers, inefficient use of soil and water resources and high cost for soil fertility improvement [4]. In addition, compounded factors, such as poor access to financing, innovation and markets, have caused soil mining. This situation is affecting the livelihood of smallholder farmers in SSA. Efforts towards 
improving agricultural productions to enhancing food security in the region should address major constraints with focus on reversing nutrient depletion from soils, mitigating the effect of drought spells and erosion, increasing nutrient and water use efficiency and adaptation of improved crop varieties. These constraints contribute to the fact that SSA is the only continent that has grown poorer in the past 35 years [5] and may be expected to remain primary concerns during the coming decades with increasingly negative consequences, unless technological, economical and socio-political measures are taken to curtail further soil degradation and to accelerate agricultural growth.

It is well established that soil fertility depletion in smallholder farms is the fundamental biophysical cause for declining per capita food production in SSA [4, 6]. There is ample evidence that the most significant biophysical constraint to increased production of both crops and livestock in SSA is the poor mineral and organic content of the soils. This constraint leads to inadequate availability of assimilated energy, protein and phosphorus for livestock production and not enough nitrogen, phosphorus and organic matter for crop production [7]. Hence, there is no way out of the poverty cycle for SSA farmers unless strong emphasis is placed on reversing nutrient depletion and increasing nutrient and water use efficiency for each particular farming system.

The use of low external input sustainable agriculture (LEISA), promoted by many donors and NGOs, presumes that organic resources are efficient in sustaining production and the natural resource base. In most cases, however, the use of organic inputs such as manure and composting is part of an internal flow of nutrients within the farm and, therefore, does not add nutrients to infertile soils. Their production is further constrained by the same limitation as food crops (poor soils and limited water). Also, the low availability of manure in Africa is inadequate to meet nutrient demand over a large area. Moreover, the low nutrient content and high labour demands for processing and application are negative factors limiting organic matter-based soil management. Several studies in West Arica [4, 8-10] have reported that cropping systems involving legume crops or short duration planted tree fallow as a means of organic matter input improved soil fertility and maize yields. However, such cropping systems result in a land use based competition between the cereal and legume crops leading in some cases to a complete loss of the cereal cropping season. Furthermore, questions remain about the potential of the organic matter technology alone to sustain high maize yields $[10,11]$.

Several other studies [8, 12, 13] concluded that the combined application of mineral and organic fertilizers, together with methods to conserve organic matter may be the most promising strategies for improving soil fertility and sustaining maize yields. The sustainability of a cropping system is primarily a function of both crop yield expressed in terms of economic returns and the associated soil health status. A quantitative characterization of complex cropping systems that include organic inputs in terms of profitability and soil health status is poorly established in the West Africa sub-region.

The objectives of this research were 1) to quantitatively evaluate three cropping systems including various organic and inorganic nutrient inputs with regard to maize grain yields and associated economic returns and 2) to determine and compare the soil health status under the three systems. The ultimate aim was to identify appropriate cropping systems that sustain maize production and mitigate the degradation of the resource base in coastal West Africa.

\section{Materials and Methods}

\subsection{Experimental Site}

The study was conducted at the University of Lomé Research Station near Lomé, Togo $\left(6^{\circ} 22^{\prime} \mathrm{N}, 1^{\circ} 13^{\prime} \mathrm{E}\right.$; altitude $=50 \mathrm{~m})$. The soil type was a rhodic Ferralsol locally called "Terres de Barre" that developed from a continental deposit [14]. This soil type covers part of the arable lands in Togo, Bénin, Ghana, and Nigeria [15] and is commonly used for maize production in coastal Western Africa. It is a welldrained soil, very low in organic matter $\left(<10 \mathrm{~g} \mathrm{~kg}^{-1}\right)$ and $\mathrm{K}$ $\left(<0.2 \mathrm{meq} 100 \mathrm{~g}^{-1}\right)$, and has total $\mathrm{P}$ contents ranging from 250 to $300 \mathrm{mg} \mathrm{kg}^{-1}$, cation exchange capacity of 3 to 4 ceq $\mathrm{kg}^{-1}$, and $\mathrm{pH}$ of 5.2 to $6.8[15,16]$. Sand content is approximately $80 \%$ at the 0 to $0.20 \mathrm{~m}$ depth, and decreases to less than $60 \%$ at the 0.50 to $1.20 \mathrm{~m}$ depth [17]. The experimental site has a slope of less than $1 \%$. Annual precipitation typically ranges from 800 to $1100 \mathrm{~mm}$ and allows for two maize growing seasons, one from April to July and another from September to December. At the onset of this experiment, the site, which has usually been used by farmers for unfertilized continuous maize cropping, was under a 1-year grass fallow.

\subsection{Crop and Soil Management}

An eight-year period (2002-2009) split-plot experiment was established with three replicates (Fig. 1). The eight-year period was segmented in 4 cycles of 2 years (2002-2003, 2004-2005, 2006-2007, and 2008-2009) with 4 growing seasons per cycle. Three cropping systems were the main plot effects and four fertilizer levels were at the subplot level.

The site was manually plowed and 12 main plots (16 x 16 $\mathrm{m})$ and 48 subplots $(8 \times 8 \mathrm{~m})$ were laid out in a spatiallybalanced complete block design [18]. Spatially-balanced complete block (SBCB) designs are a model-based approach that guarantees that the experiment is insensitive to trends, spatial correlation, or periodicity in the research domain [19]. It aims to equalize variances among treatment contrasts and allows for conventional statistical analysis methods. The cropping system scenarios include: (i) maize monoculture for the four growing seasons (MaMaMaMa) of each cycle, (ii) relay (interseeding) of a mucuna crop into the first maize crop so that it grew from June to December for the first year; in the second year, both the first and the second seasons were grown to maize (MaMuMaMa and (iii) relay of a pigeon pea crop into the first maize crop so that it grew from June to April for the first year; in the second year, both the first and 
the second seasons were grown to maize (MaPpMaMa). The maize cowpea-based cropping system (Fig. 1) is not discussed in this paper because cowpea growth was hampered by pests during the period of study.

Fertilizer treatments were applied to subplots only when maize was grown in all three cropping systems. Four subplots were treated with combinations of three levels of $\mathrm{N}(0,40$, and $\left.80 \mathrm{~kg} \mathrm{ha}^{-1}\right)$ and two levels of $\mathrm{P}\left(0\right.$ and $\left.30 \mathrm{~kg} \mathrm{ha}^{-1}\right): \mathrm{N}_{0}-\mathrm{P}_{0}$, $\mathrm{N}_{40}-\mathrm{P}_{0}, \mathrm{~N}_{40}-\mathrm{P}_{30}$, and $\mathrm{N}_{80}-\mathrm{P}_{30}$. All maize plots were fertilized with $60 \mathrm{~kg} \mathrm{~K} \mathrm{ha}{ }^{-1}$. Fertilizer $\mathrm{P}$ and $\mathrm{K}$ rates were manually broadcast as $\mathrm{P}_{2} \mathrm{O}_{5}$ and $\mathrm{K}_{2} \mathrm{O}$, respectively, at maize planting while $\mathrm{N}$ rates were manually point-placed as urea three weeks after planting at approximately $8 \mathrm{~cm}$ depth. Maize (IKENNE, the most commonly used improved variety) was planted in April and harvested in July during the first growing season, and was planted in September and harvested in December during the second season at a density of 50,000 plants $\mathrm{ha}^{-1}$. The crop was manually weeded three times during each growing season. Pigeon pea and mucuna were planted at a density of 42,000 and 35,000 plants ha ${ }^{-1}$, respectively. Crop residues from pigeon pea (after grain harvesting) and mucuna fallow (after seed harvesting) were incorporated into the soil during land preparation for the subsequent maize crop.

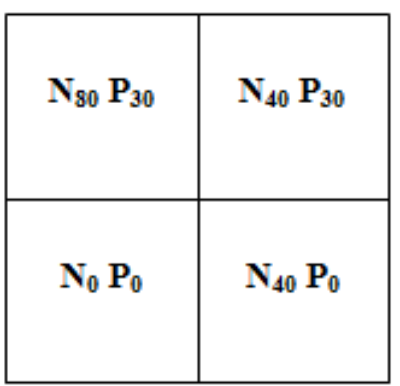

Maize-Pigeon pea

\begin{tabular}{|l|l|}
\hline $\mathbf{N}_{0} \mathbf{P}_{0}$ & $\mathbf{N}_{40} \mathbf{P}_{30}$ \\
\hline $\mathbf{N}_{40} \mathbf{P}_{0}$ & $\mathbf{N}_{80} \mathbf{P}_{30}$ \\
& \\
\hline
\end{tabular}

Continuous maize

\begin{tabular}{|l|l|}
\hline $\mathbf{N}_{40} \mathbf{P}_{30}$ & $\mathbf{N}_{40} \mathbf{P}_{0}$ \\
\hline $\mathbf{N}_{80} \mathbf{P}_{30}$ & $\mathbf{N}_{0} \mathbf{P}_{0}$ \\
& \\
\hline
\end{tabular}

Maize-Mucuna

\begin{tabular}{|l|l|}
\hline $\mathbf{N}_{40} \mathbf{P}_{30}$ & $\mathbf{N}_{40} \mathbf{P}_{0}$ \\
\hline $\mathbf{N}_{0} \mathbf{P}_{0}$ & $\mathbf{N}_{80} \mathbf{P}_{30}$ \\
& \\
\hline
\end{tabular}

Maize-Cowpea

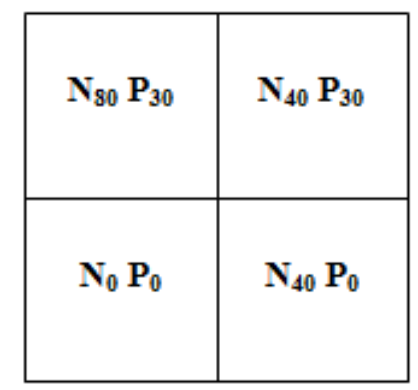

Maize-Cowpea

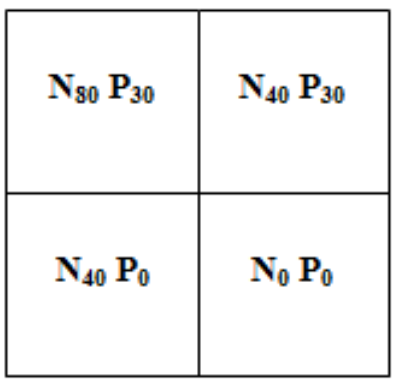

Maize-Mucuna

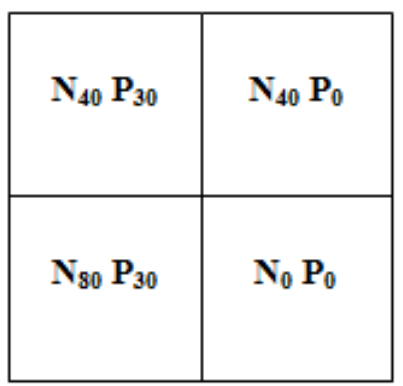

Continuous maize

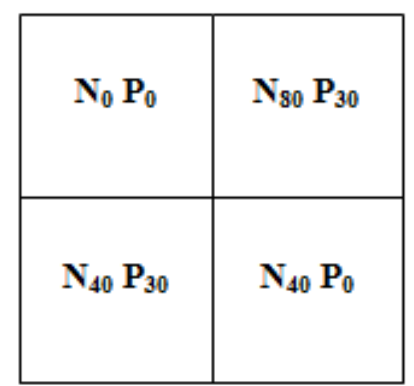

Maize-Pigeon Pea

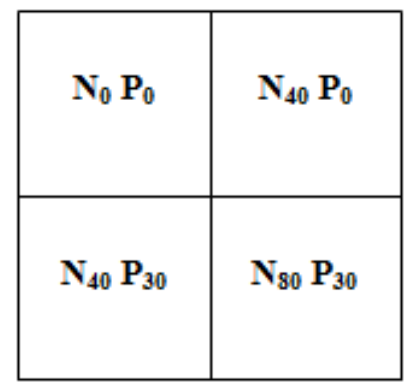

Continuous maize

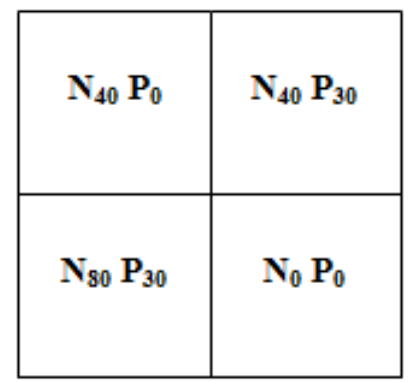

Maize-Cowpea

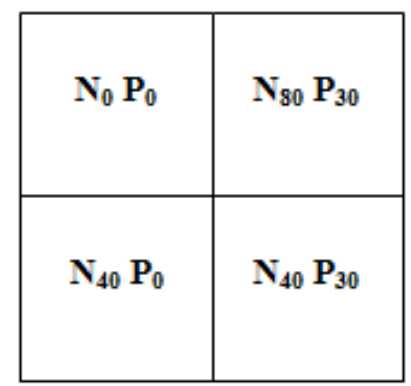

Maize-Pigeon Pea

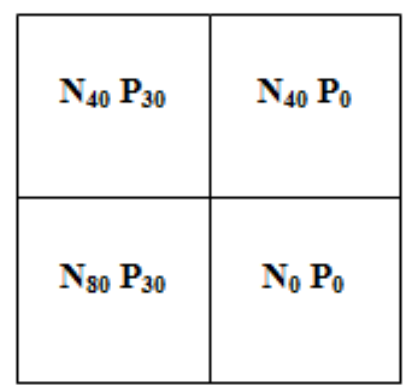

Maize-Mucuna

Figure 1. Plot layout and experimental design. 


\subsection{Data Collection}

At the onset of the experiment in 2002 (at maize planting in April), initial soil properties including total $\mathrm{C}$ and $\mathrm{N}$ contents, exchangeable bases ( $\mathrm{Ca}++, \mathrm{Mg}++, \mathrm{Na}+$ and $\mathrm{K}+$ ), $\mathrm{pH}$ and total cation exchange capacity (CEC) were measured for the first $20 \mathrm{~cm}$ soil layer $(0-20 \mathrm{~cm}$ depth) on the experiment site from twenty four composite soil samples using the standard methods of the International Institute for Tropical Agriculture [20]. At the end of the experiment in 2009 (at maize harvest in December) the same soil properties were measured on each main plot from twelve composite soil samples as described above. In addition, at the end of the experiment the water-stable aggregates (WSA) for the 0-10 $\mathrm{cm}$ soil depth from twelve composite soil samples was measured on each main plot. In preparation for the WSA measurement, soil samples were crushed by hand and passed through 2000, 500, 250 and $50 \mu \mathrm{m}$ sieve meshes. The coarse fraction and plant residues that remained on the $2000 \mu \mathrm{m}$ sieve were discarded along with the fraction that passed through the $50 \mu \mathrm{m}$ sieve. Three fractions of soil aggregate sizes remained: the 500-2000 $\mu \mathrm{m}$ fraction, referred to as macroaggregates, the $250-500 \mu \mathrm{m}$ fraction, referred to as mesoaggregates and the $50-250 \mu \mathrm{m}$ fraction, referred to as microaggregates. Samples were moistened with distilled water using a fine sprayer. A wet sieving apparatus (Eijkelkamp Giesbeek, the Netherlands) was used to determine the aggregate stability following the procedure described by [21]. Wet sieving was carried out by placing the pre-wetted soil on $500 \mu \mathrm{m}$ mesh size for the macroaggregates, $250 \mu \mathrm{m}$ mesh size for the mesoaggregates and on $50 \mu \mathrm{m}$ mesh size for the microaggregates. The sieving times were fixed at $5,15,30,60,120$ and $240 \mathrm{~min}$, except that the $5 \mathrm{~min}$ period was not used for the microaggregates. The aggregate stability was expressed as the percentage of sand-free aggregates retained on the sieve after sieving, with the initial sample also being corrected for sand content [22]. Analysis of variance (ANOVA) was performed on the gathered soil chemical and physical data sets using the MSTAT-C software, and the Student Newman-Keuls test was used to discriminate among cropping systems.

Maize grain yield was determined under each cropping system scenario from four 6-m long rows of maize from the center of each subplot that were harvested and adjusted to $14 \%$ moisture content. Due to management problems no data were collected for 2004-2005 cycle. Maize grain yield data were analyzed using the general linear mixed model with rep and rep*cropping system as random, and fertilizer level and cropping system as fixed effects. Significant effects were followed by multiple comparisons adjusted with a Bonferoni correction. The MIXED procedure in Statistical Analytical System [23] was used to run the analysis.

\subsection{Economic Analysis}

The profitability of the MaMaMaMa, MaMuMaMa and MaPpMaMa treatments was estimated through a partial budget analysis. Output consisted of the amount of cash corresponding to the maize mean grain yield for the three cycles, which was assumed to be sold at 160 F CFA (US\$0.32) $\mathrm{kg}^{-1}$, the average sale price in the country. For continuous maize cropping (MaMaMaMa), grain yield under the $\mathrm{N}_{80} \mathrm{P}_{30}$ fertilization was used, and average yield values for the four mineral fertilization treatments were used for the cropping systems involving mucuna and pigeon pea (MaMuMaMa and MaPpMaMa). The inputs consisted of the costs associated with each cropping system, including those for soil preparation, seed, crop planting and related tasks, fertilizer purchase and application, crop weeding and crop harvesting and associated tasks. Mucuna and pigeon pea grain yield sale values and harvesting costs were not included in the budget because mucuna grain is a non-food product and has no sale value as seed at the farmers' level in the country. Pigeon pea grain is used as food mainly in rural areas, but its sale value is not well established. No weeding costs were associated with the mucuna and pigeon pea crops as they were relayed into maize crops and because of their competitive growth and ability to provide soil cover. Labor costs were determined to be 1500 FCFA (US\$3.0) per person day, and fertilizer costs were based on prices used by the Direction Régionale de l'Agriculture, de l'Elevage et de la Pêche (DRAEP) (pers. comm.) Estimates of labor for maize, mucuna and pigeon pea crops in a growing season as defined in the MaMaMaMa, MaMuMaMa and MaPpMaMa systems are presented in Table 1, and are based on labor records from the experiment.

Table 1. Estimated labor associated with a season of maize, mucuna and pigeon crop under a cycle of continuous maize, maize mucuna-based, and maize pigeon pea-based cropping systems.

\begin{tabular}{llll}
\hline & MaMaMaMa & MaMuMaMa & person day ha . $^{-1}$ \\
\hline Soil preparation & & 0 & 0 \\
Planting and related tasks & 30 & 12 & 12 \\
Weeding & 35 & 0 & 0 \\
Fertilizer application & 90 & 0 & 0 \\
Harvesting and related tasks & 20 & 0 & 0 \\
Total labor & 70 & 12 & 12 \\
Total labor cost ${ }^{\mathbb{I l}}\left(\mathrm{F} \mathrm{CFA}^{\S}\right)$ & 245 & 367500 & 18000 \\
\hline
\end{tabular}




\section{Results and Discussion}

\subsection{Maize Grain Production}

Table 2. Mean maize grain yields $\left(\mathrm{Mg} \mathrm{ha}^{-1}\right)$ for each growing season, year and the 2-years cycle period.

\begin{tabular}{|c|c|c|c|c|c|c|c|}
\hline \multirow{2}{*}{ Cropping systems } & \multicolumn{3}{|c|}{ Year 1} & \multicolumn{3}{|c|}{ Year 2} & \multirow{2}{*}{$\begin{array}{l}\text { Year } 1+\text { Year } 2 \\
\text { Total }\end{array}$} \\
\hline & GS $^{\mathrm{T}} 1$ & GS2 & Total & GS1 & GS2 & Total & \\
\hline \multicolumn{8}{|l|}{ Cycle 2002-2003 } \\
\hline \multicolumn{8}{|l|}{$\mathrm{MaMaMaMa}^{ \pm}$} \\
\hline $\mathrm{N}_{0} \mathrm{P}_{0}$ & 6.1 & $3.7 \mathrm{a}$ & $9.8 \mathrm{a}$ & $4.5 \mathrm{a}$ & $2.5 \mathrm{a}$ & $7.0 \mathrm{a}$ & $16.8 \mathrm{a}$ \\
\hline $\mathrm{N}_{40} \mathrm{P}_{0}$ & 6.3 & $3.8 \mathrm{a}$ & $10.1 \mathrm{a}$ & $5.7 b$ & $2.7 \mathrm{a}$ & $8.4 \mathrm{a}$ & $18.5 \mathrm{ab}$ \\
\hline $\mathrm{N}_{40} \mathrm{P}_{30}$ & 6.3 & $3.9 \mathrm{a}$ & $10.2 \mathrm{a}$ & $5.6 b$ & $2.8 \mathrm{a}$ & $8.4 \mathrm{a}$ & $18.6 \mathrm{ab}$ \\
\hline $\mathrm{N}_{80} \mathrm{P}_{30}$ & 6.5 & $4.0 \mathrm{a}$ & $10.5 \mathrm{a}$ & $5.9 \mathrm{~b}$ & $3.7 b$ & $9.6 b$ & $20.1 b$ \\
\hline Mean & 6.3 & 3.8 & 10.1 & 5.4 & 2.9 & 8.3 & 18.5 \\
\hline \multicolumn{8}{|l|}{ MaMuMaMa } \\
\hline $\mathrm{N}_{0} \mathrm{P}_{0}$ & 6.1 & $\S$ & $6.1 b$ & $6.9 \mathrm{~b}$ & $4.4 \mathrm{~b}$ & $11.3 b$ & $17.5 \mathrm{ab}$ \\
\hline $\mathrm{N}_{40} \mathrm{P}_{0}$ & 6.3 & $\S$ & $6.3 b$ & $6.8 b$ & $4.6 b$ & $11.4 \mathrm{~b}$ & $17.9 \mathrm{ab}$ \\
\hline $\mathrm{N}_{40} \mathrm{P}_{30}$ & 6.3 & $\S$ & $6.3 b$ & $7.0 \mathrm{~b}$ & $4.3 b$ & $11.3 b$ & $17.5 \mathrm{ab}$ \\
\hline $\mathrm{N}_{80} \mathrm{P}_{30}$ & 6.5 & $\S$ & $6.5 b$ & $7.0 \mathrm{~b}$ & $4.4 \mathrm{~b}$ & $11.4 \mathrm{~b}$ & $17.9 \mathrm{ab}$ \\
\hline Mean & 6.3 & & 6.3 & 6.9 & 4.4 & 11.3 & 17.6 \\
\hline \multicolumn{8}{|l|}{$\mathrm{MaPpMaMu}$} \\
\hline $\mathrm{N}_{0} \mathrm{P}_{0}$ & 6.1 & $\S$ & $6.1 b$ & $6.6 b$ & $3.8 \mathrm{~b}$ & $10.4 b$ & $16.7 \mathrm{a}$ \\
\hline $\mathrm{N}_{40} \mathrm{P}_{0}$ & 6.3 & $\S$ & $6.3 b$ & $6.7 b$ & $4.1 b$ & $10.8 b$ & $17.2 \mathrm{a}$ \\
\hline $\mathrm{N}_{40} \mathrm{P}_{30}$ & 6.3 & $\S$ & $6.3 b$ & $6.6 b$ & $3.8 \mathrm{~b}$ & $10.4 b$ & $16.7 \mathrm{a}$ \\
\hline $\mathrm{N}_{80} \mathrm{P}_{30}$ & 6.5 & $\S$ & $6.5 b$ & $6.7 b$ & $4.2 \mathrm{~b}$ & $10.9 b$ & $17.1 \mathrm{a}$ \\
\hline Mean & 6.3 & & 6.3 & 6.6 & 4.0 & 10.6 & 17.1 \\
\hline \multicolumn{8}{|l|}{ Cycle 2006-2007 } \\
\hline \multicolumn{8}{|l|}{ MaMaMaMa } \\
\hline $\mathrm{N}_{0} \mathrm{P}_{0}$ & $2.9 \mathrm{a}$ & $1.9 \mathrm{~b}$ & $4.8 \mathrm{c}$ & $2.2 \mathrm{c}$ & $1.4 \mathrm{c}$ & $3.6 \mathrm{c}$ & $8.4 \mathrm{c}$ \\
\hline $\mathrm{N}_{40} \mathrm{P}_{0}$ & $4.6 b$ & $1.8 b$ & $6.4 b$ & $3.4 \mathrm{a}$ & $1.8 \mathrm{c}$ & $5.2 \mathrm{~d}$ & $11.6 \mathrm{~d}$ \\
\hline $\mathrm{N}_{40} \mathrm{P}_{30}$ & $5.0 \mathrm{~b}$ & $2.1 \mathrm{~b}$ & $7.1 \mathrm{~d}$ & $3.8 \mathrm{a}$ & $1.7 \mathrm{c}$ & $5.5 \mathrm{~d}$ & $12.6 \mathrm{~d}$ \\
\hline $\mathrm{N}_{80} \mathrm{P}_{30}$ & 6.2 & $2.6 \mathrm{c}$ & $8.8 \mathrm{a}$ & $4.0 \mathrm{a}$ & $2.5 \mathrm{a}$ & $6.5 \mathrm{~d}$ & $15.3 \mathrm{e}$ \\
\hline Mean & 4.7 & 2.1 & 6.8 & 3.4 & 1.9 & 5.2 & 12.0 \\
\hline \multicolumn{8}{|l|}{ MaMuMaMa } \\
\hline $\mathrm{N}_{0} \mathrm{P}_{0}$ & 6.3 & $\S$ & $6.3 b$ & $6.6 b$ & $4.0 \mathrm{~b}$ & $10.6 b$ & $16.9 \mathrm{a}$ \\
\hline $\mathrm{N}_{40} \mathrm{P}_{0}$ & 6.2 & $\S$ & $6.2 b$ & $6.8 \mathrm{~b}$ & $4.2 b$ & $11.0 \mathrm{~b}$ & $17.2 \mathrm{a}$ \\
\hline $\mathrm{N}_{40} \mathrm{P}_{30}$ & 6.5 & $\S$ & $6.5 b$ & $7.0 \mathrm{~b}$ & $4.2 \mathrm{~b}$ & $11.2 \mathrm{~b}$ & $17.7 \mathrm{ab}$ \\
\hline $\mathrm{N}_{80} \mathrm{P}_{30}$ & 6.6 & $\S$ & $6.6 b$ & $6.9 \mathrm{~b}$ & $4.4 \mathrm{~b}$ & $11.3 b$ & $17.9 \mathrm{ab}$ \\
\hline Mean & 6.4 & & 6.4 & 6.8 & 4.2 & 11.0 & 17.4 \\
\hline \multicolumn{8}{|l|}{ MaPpMaMa } \\
\hline $\mathrm{N}_{0} \mathrm{P}_{0}$ & 5.4 & $\S$ & $5.4 b$ & $5.6 \mathrm{~b}$ & $3.3 b$ & $8.9 \mathrm{a}$ & $14.3 \mathrm{e}$ \\
\hline $\mathrm{N}_{40} \mathrm{P}_{0}$ & 5.5 & $\S$ & $5.5 b$ & $5.6 \mathrm{~b}$ & $3.7 \mathrm{~b}$ & $9.3 \mathrm{a}$ & $14.8 \mathrm{e}$ \\
\hline $\mathrm{N}_{40} \mathrm{P}_{30}$ & 6.0 & $\S$ & $6.0 \mathrm{~b}$ & $6.3 b$ & $3.7 b$ & $10.0 \mathrm{~b}$ & $16.0 \mathrm{a}$ \\
\hline $\mathrm{N}_{80} \mathrm{P}_{30}$ & 6.2 & $\S$ & $6.2 b$ & $6.4 \mathrm{~b}$ & $3.9 \mathrm{~b}$ & $10.3 b$ & $16.5 \mathrm{a}$ \\
\hline Mean & 5.8 & & 5.8 & 6.0 & 3.7 & 9.6 & 15.4 \\
\hline \multicolumn{8}{|l|}{ Cycle 2008-2009 } \\
\hline \multicolumn{8}{|l|}{ MaMaMaMa } \\
\hline $\mathrm{N}_{0} \mathrm{P}_{0}$ & $1.8 \mathrm{c}$ & $1.0 \mathrm{~d}$ & $2.8 \mathrm{e}$ & $1.2 \mathrm{~d}$ & $0.8 \mathrm{~d}$ & $2.0 \mathrm{e}$ & $4.8 \mathrm{f}$ \\
\hline $\mathrm{N}_{40} \mathrm{P}_{0}$ & $2.8 \mathrm{a}$ & $1.2 \mathrm{~d}$ & $4.0 \mathrm{c}$ & $1.5 \mathrm{c}$ & $0.9 \mathrm{~d}$ & $2.5 \mathrm{e}$ & $6.5 \mathrm{~g}$ \\
\hline $\mathrm{N}_{40} \mathrm{P}_{30}$ & $3.0 \mathrm{a}$ & $1.1 \mathrm{~d}$ & $4.1 \mathrm{c}$ & $1.7 \mathrm{c}$ & $0.9 \mathrm{~d}$ & $2.6 \mathrm{e}$ & $6.7 \mathrm{~g}$ \\
\hline $\mathrm{N}_{80} \mathrm{P}_{30}$ & $4.2 \mathrm{~b}$ & $1.8 \mathrm{~b}$ & $6.0 \mathrm{~b}$ & $3.2 \mathrm{a}$ & $1.6 \mathrm{c}$ & $4.8 \mathrm{~d}$ & $10.8 \mathrm{~h}$ \\
\hline Mean & 3.0 & 1.3 & 4.2 & 1.9 & 1.1 & 3.0 & 7.2 \\
\hline \multicolumn{8}{|l|}{ MaMuMaMa } \\
\hline $\mathrm{N}_{0} \mathrm{P}_{0}$ & 6.1 & $\S$ & $6.1 b$ & $6.4 b$ & $4.2 \mathrm{~b}$ & $10.6 b$ & $16.7 \mathrm{a}$ \\
\hline $\mathrm{N}_{40} \mathrm{P}_{0}$ & 6.2 & $\S$ & $6.2 b$ & $6.3 b$ & $4.3 b$ & $10.6 b$ & $16.8 \mathrm{a}$ \\
\hline $\mathrm{N}_{40} \mathrm{P}_{30}$ & 6.3 & $\S$ & $6.3 b$ & $6.8 b$ & $4.0 \mathrm{~b}$ & $10.8 b$ & $17.1 \mathrm{a}$ \\
\hline $\mathrm{N}_{80} \mathrm{P}_{30}$ & 6.2 & $\S$ & $6.2 b$ & $6.8 b$ & $4.5 b$ & $11.3 b$ & $17.5 \mathrm{a}$ \\
\hline Mean & 6.2 & & 6.2 & 6.6 & 4.3 & 10.8 & 17.0 \\
\hline \multicolumn{8}{|l|}{ МаРрМаМа } \\
\hline $\mathrm{N}_{0} \mathrm{P}_{0}$ & $4.8 \mathrm{~b}$ & $\S$ & $4.8 \mathrm{c}$ & $5.2 b$ & $3.0 \mathrm{~b}$ & $8.2 \mathrm{a}$ & $13.0 \mathrm{e}$ \\
\hline $\mathrm{N}_{40} \mathrm{P}_{0}$ & $5.0 \mathrm{~b}$ & $\S$ & $5.0 \mathrm{c}$ & $5.2 \mathrm{~b}$ & $3.5 b$ & $8.7 \mathrm{a}$ & $13.7 \mathrm{e}$ \\
\hline $\mathrm{N}_{40} \mathrm{P}_{30}$ & 5.7 & $\S$ & $5.7 b$ & $5.9 \mathrm{~b}$ & $3.3 b$ & $9.2 \mathrm{a}$ & $14.9 \mathrm{e}$ \\
\hline $\mathrm{N}_{80} \mathrm{P}_{30}$ & 6.2 & $\S$ & $6.2 b$ & $6.2 b$ & $3.7 b$ & $9.9 \mathrm{~b}$ & $16.1 \mathrm{a}$ \\
\hline Mean & 5.4 & & 5.4 & 5.6 & 3.4 & 9.0 & 14.4 \\
\hline
\end{tabular}
and fertilization pattern in the first year of the study (Table 2). 
Grain yield from all cropping system scenarios ranged from 6.1 to 6.5 and 3.7 to $4.0 \mathrm{Mg} \mathrm{ha}^{-1}$ during the first and the second growing seasons, respectively. The yield depression in the second growing season as compared with the first growing season, which was also observed during the whole period of the study, presumably resulted from lower rainfall $(154.1 \mathrm{~mm})$ compared with the first growing season (529.6 $\mathrm{mm})$, similar to previous research [24]. The limited yield response to $\mathrm{N}$ and $\mathrm{P}$ occurred primarily as a result of the high initial soil $\mathrm{NO}_{3}-\mathrm{N}$ content (46.1 kg ha ${ }^{-1}$ ) and labile $\mathrm{P}$ content (368.9 $\left.\mathrm{kg} \mathrm{ha}^{-1}\right)$. In addition, the lack of yield response suggests that mucuna and pigeon pea crops that were relayed 50 to 60 days after maize planting did not significantly reduce maize nutrient use and growth. Reference [25] found that relay of mucuna into maize 30 days after maize planting resulted in maize yield depression due to competition, and suggested a longer time period between the planting times of the two crops.

In the second year, the effects of fertilizer and cropping system and their interaction were significant. During the first growing season under continuous maize (MaMaMaMa), grain yield was significantly lower under $\mathrm{N}_{0} \mathrm{P}_{0}$ fertilization compared with those for others $\left(\mathrm{N}_{40} \mathrm{P}_{0}, \mathrm{~N}_{40} \mathrm{P}_{30}\right.$ and $\mathrm{N}_{80} \mathrm{P}_{30}$, Table 2). The lack of response to $P$ fertilization and the interaction between $\mathrm{N}$ and $\mathrm{P}$ presumably resulted from the high (368.9 $\mathrm{kg} \mathrm{P} \mathrm{ha}^{-1}$ ) April 2002 soil $\mathrm{P}$ content. Except for the $\mathrm{N}_{0} \mathrm{P}_{0}$ fertilization level under MaMaMaMa, grain yield was similar for all fertilization levels under the three cropping systems (Table 2). This demonstrates that the interaction of fertilizer rate*cropping system was significant and that nutrient restitution to soil through incorporation of the cover crops prevented the need for additional fertilizer. During the second growing season of the second year, grain yields for the highest fertilization level $\left(\mathrm{N}_{80} \mathrm{P}_{30}\right)$ under MaMaMaMa and all fertilization levels under MaMuMaMa and MaPpMaMa were similar (3.7 to $4.6 \mathrm{Mg} \mathrm{ha}^{-1}$ ), but higher than the three other fertilization levels $\left(\mathrm{N}_{0} \mathrm{P}_{0}, \mathrm{~N}_{40} \mathrm{P}_{0}\right.$ and $\mathrm{N}_{40} \mathrm{P}_{30}, 2.5$ to $2.8 \mathrm{Mg} \mathrm{ha}^{-1}$ ) under MaMaMaMa. This, again, indicates that the effects of fertilization level on grain yield varied with cropping system. In each of the two growing seasons of the second year of the study, maize grain yields were similar or slightly higher for MaMuMaMa and MaPpMaMa and lower for MaMaMaMa compared to those in the corresponding seasons of the first year (Table 2). These results indicate that MaMuMaMa and MaPpMaMa sustained higher maize yields at minimal mineral fertilizer rates.

In the first year of the study, two-season cumulative grain yields for MaMaMaMa were higher (9.8 to $10.5 \mathrm{Mg} \mathrm{ha}^{-1}$, Table 2) than those for MaMuMaMa and MaPpMaMa (6.2 to $6.5 \mathrm{Mg} \mathrm{ha}^{-1}$ ) because the latter did not allow for a second maize crop. In the second year, however, yearly cumulative grain yields were higher (10.4 to $11.4 \mathrm{Mg} \mathrm{ha}^{-1}$ ) for MaMuMaMa and MaPpMaMa than those for MaMaMaMa (7.0 to $9.6 \mathrm{Mg} \mathrm{ha}^{-1}$ ). On a cycle basis (2-years cumulative value) grain yield data showed that the highest fertilization level $\left(\mathrm{N}_{80} \mathrm{P}_{30}\right)$ under MaMaMaMa resulted in higher yield
(20.1 $\left.\mathrm{Mg} \mathrm{ha}{ }^{-1}\right)$ than the $\mathrm{N}_{0} \mathrm{P}_{0}\left(16.8 \mathrm{Mg} \mathrm{ha}^{-1}\right)$ and all fertilization levels under MaPpMaMa (16.7 to $17.2 \mathrm{Mg} \mathrm{ha}^{-1}$, Table 2). Except for the $\mathrm{N}_{80} \mathrm{P}_{30}$ under MaMaMaMa, all fertilization levels under MaMaMaMa, MaMuMaMa and MaPpMaMa provided similar cycle-based grain yields (16.7 to $18.6 \mathrm{Mg} \mathrm{ha}^{-1}$ ). Only significant additional fertilizer allowed for higher yields $\left(20.1 \mathrm{Mg} \mathrm{ha}^{-1}\right.$ under $\left.\mathrm{N}_{80} \mathrm{P}_{30}\right)$ for MaMaMaMa. On average (mean value for all fertilization levels), annual maize grain yield in the fallow year increased by $60.3 \%$ under MaMaMaMa as compared with yields under MaMuMaMa and MaPpMaMa, but in the non-fallow year yield increased by 28 and $22 \%$ under MaMuMaMa and MaPpMaMa, respectively, as compared with yield under MaMaMaMa. On a cycle basis, mean yield value was 5.1 and 8.2\% higher than those for MaMuMaMa and MaPpMaMa, respectively, indicating that in short term continuous maize cropping proved superiority over maize-cover cropping based systems.

During the first year of the 2006-2007 cycles, maize grain yields were lowest, intermediate and highest for the $\mathrm{N}_{0} \mathrm{P}_{0}$, $\mathrm{N}_{40} \mathrm{P}_{0}$ and $\mathrm{N}_{40} \mathrm{P}_{30}$, and $\mathrm{N}_{80} \mathrm{P}_{30}$, respectively, for the MaMaMaMa system (Table 2), indicating that the soil fertility has decreased and $\mathrm{N}$ and $\mathrm{P}$ effects were measurable. However, the fertilization level did not affect grain yields under the MaMuMaMa and MaPpMaMa systems which were similar to the yield for the highest fertilization rate for the continuous maize system. Unlike the 2002-2003 cycle where the first year based cumulative yields for all fertilization levels under the continuous maize system were systematically higher than those under the MaMuMaMa and MaPpMaMa systems, yearly cumulative yields were lowest and highest under the $\mathrm{N}_{0} \mathrm{P}_{0}$ and $\mathrm{N}_{80} \mathrm{P}_{30}$ fertilization levels for MaMaMaMa and intermediate under all levels for the mucuna and pigeon pea based systems (Table 2). This indicates that even with the loss of the second growing season the latter systems challenged the continuous maize system. During the second year of the cycle, seasonal and annual grain yields were in general similar for all fertilization levels under MaMuMaMa and MaPpMaMa systems, but systematically higher than those for all fertilization levels under the MaMaMaMa system. This suggests that continuous cultivation contributed yield depression even at a high mineral fertilization level. Annual mean (average value for all fertilization levels) maize grain yield in the fallow year increased by 6.2 and $17.2 \%$ under MaMaMaMa as compared with yields under MaMuMaMa and MaPpMaMa, respectively, but in the non-fallow year yields were 111.5 and 84.6\% higher under MaMuMaMa and MaPpMaMa, respectively, than mean yield under MaMaMaMa. On a cycle basis, mean yield values increased by 45 and $28.3 \%$ under MaMuMaMa and MaPpMaMa, respectively, as compared with value under MaMaMaMa.

The yield results for the first year of the 2008-2009 cycle followed similar trends as those for the second year of the 2006-207 cycle (Table 2) as described above. But during the second year of the 2008-2009 cycles, yield depression was 
very accentuated leading to seasonal and annual values ranging from 0.8 to 4.8 and from 3.0 to $11.3 \mathrm{Mg} \mathrm{ha}^{-1}$ for MaMaMaMa and, MaMuMaMa and MaPpMaMa, respectively. Annual mean (average value for all fertilization levels) maize grain yield in the fallow year increased by 47.6 and 28.6\% under MaMuMaMa and MaPpMaMa, respectively, as compared with yield under MaMaMaMa, and in the nonfallow year yields were 260 and $200 \%$ higher under MaMuMaMa and MaPpMaMa, respectively, than mean yield under MaMaMaMa. On a cycle basis, mean yield values increased by 136.1 and $100 \%$ under MaMuMaMa and MaPpMaMa, respectively, as compared with value under MaMaMaMa.

Annual mean maize grain yield results from this study (except the first year of the experiment) agreed with those of $[26,27]$ in that a mucuna cover crop may allow for similar or higher yearly maize grain yields even if it causes the loss of the second maize crop of the year. Such a yield increase in the fallow year occurred during the 2008-2009 cycle of this study at a magnitude of 47.6 and $28.6 \%$ under mucuna and pigeon pea fallow, respectively. The magnitude of the mean yield increase under MaMuMaMa and MaPpMaMa in the non fallow year and on a cycle basis ranged from 27.7 to $260 \%$, which corroborate reasonably well values ranging from 24 to $220 \%$ published by [28, 29].

\subsection{Partial Budget Analysis}

Results of the budget of inputs (total costs associated with MaMaMaMa, MaMuMaMa and MaPpMaMa) and corresponding outputs (cash values of maize grain yield for the four growing seasons) are presented in Table 3.

The outputs from MaMuMaMa (2,768,000 FCFA) and MaPpMaMa (2,496,000 FCFA) were 12.3 and $1.3 \%$ higher, respectively, than the 2,464,000 FCFA output from MaMaMaMa with high fertilization level $\left(\mathrm{N}_{80} \mathrm{P}_{30}\right)$. However, the input associated with MaMaMaMa was 28.9 and $30.1 \%$ higher than those for MaMuMaMa and MaPpMaMa, respectively. The balance was positive in all cases, but was on a per hectare basis $105.1 \%(1,377,871$ FCFA = US\$2,756) and $66.5 \%(1,118,871 \mathrm{~F}$ CFA $=$ US\$2,238) higher for MaMuMaMa and MaPpMaMa, respectively, compared to that $(671,868$ FCFA $=$ US\$1,344) of MaMaMaMa with $\mathrm{N}_{80} \mathrm{P}_{30}$ mineral fertilization (Table 3). The cash value superiority of MaMuMaMa and MaPpMaMa over MaMaMaMa may be accentuated if other benefits such as mucuna and pigeon pea grain values are accounted for.

Table 3. Partial budget analysis for continuous maize, maize mucuna-based and maize pigeon pea-based cropping systems.

\begin{tabular}{llll}
\hline & MaMaMaMa & MaMuMaMa & MaPpMaMa \\
\hline & & F CFA ha ${ }^{-1}$ & $2,496,000$ \\
Output (Maize grain value) & $+2,464,000$ & $2,768,000$ & $1,377,129$ \\
Input (labor +seeds + fertilizer) & $-1,792,192$ & $1,390,129$ & $(1,120,500)$ \\
Labor & $(1,470,000)$ & $(1,120,500)$ & $(72,000)$ \\
Seeds & $(76,000)$ & $(85,000)$ & $(184,629)$ \\
Fertilizer & $(246,172)$ & $(184,629)$ & $+1,118,871($ US $\$ 2,238)$ \\
Balance & $+671,828$ (US $\$ 1,344)$ & $+1,377,871($ US $\$ 2,756)$ & \\
\hline
\end{tabular}

\subsection{Soil Physical and Chemical Properties}

to cropping system (Table 4).

Soil $\mathrm{pH}$ and stored total $\mathrm{N}$ in the soil were not responsive

Table 4. Soil properties at the onset (2002) and at the end (2009) of the experiment.

\begin{tabular}{|c|c|c|c|c|}
\hline \multirow{2}{*}{ Soil Properties } & \multirow{2}{*}{ Year 2002} & \multicolumn{3}{|l|}{ Year 2009} \\
\hline & & МаMaMaMa & МаMuMaМa & МаРрМаМа \\
\hline \multicolumn{5}{|l|}{ Chemical Properties } \\
\hline $\mathrm{pH}\left(\mathrm{H}_{2} \mathrm{O}\right)$ & 7.22 & 7.19 & 7.35 & 7.10 \\
\hline Total C (\%) & $0.71 \mathrm{a}$ & $0.83 \mathrm{a}$ & $1.10 \mathrm{~b}$ & $1.20 \mathrm{~b}$ \\
\hline Total N (\%) & 0.06 & 0.08 & 0.11 & 0.09 \\
\hline \multicolumn{5}{|c|}{ Exchangeable bases $\left(\mathrm{cmol} \mathrm{kg}^{-1}\right)$} \\
\hline $\mathrm{Ca}++$ & $30.75 \mathrm{a}$ & $38.37 \mathrm{a}$ & $64.75 b$ & $66.63 b$ \\
\hline $\mathrm{Mg}++$ & $7.75 \mathrm{a}$ & $7.12 \mathrm{a}$ & $10.44 b$ & $12.62 \mathrm{~b}$ \\
\hline $\mathrm{Na}+$ & $6.75 \mathrm{a}$ & $5.0 \mathrm{~b}$ & $7.37 \mathrm{a}$ & $6.75 \mathrm{a}$ \\
\hline $\mathrm{K}+$ & $5.63 \mathrm{a}$ & $3.38 \mathrm{~b}$ & $7.25 \mathrm{c}$ & $4.40 \mathrm{~b}$ \\
\hline Total CEC $\left(\mathrm{cmol} \mathrm{kg}^{-1}\right)$ & $2.35 \mathrm{a}$ & $2.00 \mathrm{~b}$ & $2.73 \mathrm{c}$ & $2.76 \mathrm{c}$ \\
\hline \multicolumn{5}{|l|}{ Physical Properties } \\
\hline \multicolumn{5}{|l|}{$\mathrm{WSA}_{240} \min (\%)$} \\
\hline Macroaggregates & & $65.60 \mathrm{a}$ & $80.40 \mathrm{~b}$ & $71.50 \mathrm{c}$ \\
\hline Mesoaggregates & & 73.30 & 74.20 & 74.30 \\
\hline Microaggregates & & 97.60 & 97.60 & 97.50 \\
\hline
\end{tabular}


Unlike continuous maize which did not improve the soil $\mathrm{C}$ stock, mucuna and pigeon pea based cropping systems enhanced carbon sequestration, leading to an increase in the initial soil total $\mathrm{C}$ content by 55 and $69 \%$, respectively. Similarly, mucuna and pigeon pea based systems increased soil exchangeable $\mathrm{Ca}^{2+}$ by 110 and $117 \%$, respectively, and $\mathrm{Mg}^{2+}$ by 33 and $63 \%$, respectively, whiles no improvement was observed under the continuous maize cropping (Table 4). Continuous maize and pigeon pea based cropping systems resulted in soil exchangeable $\mathrm{K}^{+}$depletion by 40 and $22 \%$, respectively, but the mucuna based system increased exchangeable $\mathrm{K}^{+}$by $29 \%$. Exchangeable $\mathrm{Na}^{+}$was maintained in the soil by mucuma and pigeon pea based systems, but was depleted by $35 \%$ under continuous maize cropping. A decrease of total CEC by $17.5 \%$ occurred under the MaMaMaMa, but MaMuMaMa and MaPpMaMa increased total CEC by 16 and 17\%, respectively (Table 4). In a 2-years study to assess the effect of several cover crops including pigeon pea on soil physical and chemical properties in Burkina Faso, [30] found that soil exchangeable $\mathrm{Ca}^{2+}, \mathrm{Mg}^{2+}$, and $\mathrm{Na}^{+}$, total $\mathrm{CEC}$ and total $\mathrm{C}$ were not affected by cover crop. This disagrees with the findings of our study which however reasonably corroborated research results published by [31] in that mucuna cover crop raised soil total $\mathrm{C}$, exchangeable $\mathrm{Ca}^{2+}$ and $\mathrm{Mg}^{2+}$ by 81,14 , and $28 \%$, respectively. Results of this study were also largely similar to those published by [32] who used tithonia green manure and water hyacinth compost as organic sources to restore soil fertility and found increases in soil exchangeable $\mathrm{Ca}^{2+}, \mathrm{Mg}^{2+}$, $\mathrm{K}^{+}, \mathrm{Na}^{+}$, and total CEC in the range of 61 to 74,127 to 149 , 172 to 187,79 to 83 and 78 to $94 \%$, respectively.

The stability of the mesoaggregates and microaggregates was not affected by cropping system (Table 4). However, $65.60,80.40$ and $71.50 \%$ of the macroaggregates were water stable under MaMaMaMa, MaMuMaMa and MaPpMaMa, respectively. This indicates that the mucuna and pigeon based cropping systems raised the macroaggregates stability by 22.6 and $9.0 \%$, respectively, as compared with the continuous maize cropping, and mucuna based system was superior to pigeon pea based system by $12.44 \%$. These results were comparable to the over $60 \%$ water stable macroaggregates found by [33] as a result in part of a mucuna cover crop, and reasonably agreed with [34] who reported a $26 \%$ increase in water stable macroaggregate stability due in part to the use of compost.

\section{Conclusions}

A threshold of 60 days after maize planting appeared to be an appropriate timing to relaying mucuna and pigeon pea into a maize crop. Relay of mucuna and pigeon pea into maize in alternate years sustained higher maize yields with minimal mineral fertilizer rates compared to the continuous maize system, but such a superiority of the cover cropping based system was more evident in non-fallow years. In a short term (over the first two to four years), continuous maize system may provide higher grain yields when using high levels of mineral fertilization. Maize cropping with mucuna and pigeon pea as cover crops in alternate years proved largely more profitable in terms of economic returns compared to continuous maize cropping even with high mineral fertilization levels, with the profit substantially increasing over time. Continuous maize practice systematically induced soil degradation, but the maize mucuna and pigeon pea-based maize cropping systems enhanced soil physical and chemical properties, with a greater performance of the mucuna-based system.

\section{References}

[1] Henao S, Baanante C. Agricultural production and soil nutrient mining in Africa: Implication for resource conservation and policy development. IFDC, Muscle shoals, AL 35662, USA, 75p, 2006.

[2] Liniger HP, Mekdaschi Studer R, Hauert C, Gurtner M. La pratique de la gestion durable des terres. Directives et bonnes pratiques en Afrique subsaharienne. TerrAfrica, Panorama mondial des approches et technologies de conservation (WOCAT) et Organisation des Nations Unies pour l'alimentation et l'agriculture (FAO). Rome, Italie, 243p, 2011.

[3] Kihara J, Fatondji D, Jones JW, Hoogenboom G, Tabo R, Bationo A. Improving Soil Fertility Recommendations in Africa using the Decision Support System for Agrotechnology Transfer (DSSAT). VIII, 187, 2012.

[4] IFDC (International Fertilizer Development Center). Mainstreaming pro-poor fertilizer access and innovative practices in West Africa. IFAD Technical Assistance Grant No. 1174 report. Muscle Shoals, Alabama, USA, 2013.

[5] IFPRI. Reaching Sustainable Food Security for All by 2020. PDF file and Powerpoint presentation available at www.ifpri.org/ 2020 vision. Rome, 2002.

[6] Bationo A, Hartemink A, Lungu O, Naimi M, Okoth P, Smaling E, Thiombiano L, Waswa B. Knowing the African Soils to Improve Fertilizer Recommendations. P 19-42. VIII, $187 \mathrm{p}, 2012$.

[7] IFDC (International Fertilizer Development Center). Development and Dissemination of Sustainable Integrated Soil Fertility Management Practices for Smallholder Farmers in Sub-Saharan Africa. Technical Bulletin IFDC - T-71. Muscle Shoals, Alabama, USA, 2009.

[8] Detchinli KS. Analyses multidimensionnelles des effets de trois systèmes culturaux sur le rendement du maïs (Zea mays L.) et le sol : bilan d'une expérimentation sur sols ferralitiques au Togo méridional. Diplôme d'Etudes Approfondies, Sciences des Agroressources et Génie de l'Environnement, option: Sciences des Agroressources, février 2013. Ecole Supérieure d'Agronomie de l'Université de Lomé, Togo. 41p.

[9] SARI. Savanna Agricultural Research Institute (SARI) annual Report for 2005, Nyakpala, Ghana.105p, 2005.

[10] Sanchez PA, Jawa BBA. Soil fertility replenishment takes off in East and Southern Africa. p. 23-45. In B. Vanlauwe et al. (ed.). Integrated plant nutrient management in Sub-Saharan Africa: from concept to practice. CABI, Wallingford, UK, 2002. 
[11] Place F, Christopher B, Barett H, de Freeman JA, Ramisch J, Vaulauwe B. Prospect for integrated soil fertility management using organic and inorganic inputs: evidence from smallholder African agricultural systems. Nairobi, Kenya, 24 p, 2003.

[12] Kombiok JM, Buah JSS, Sogbedji JM. Enhancing Soil Fertility for Cereal Crop Production Through Biological Practices and the Integration of Organic and In-Organic Fertilizers in Northern Savanna Zone of Ghana. In: Soil Fertility. R. Issaka (ed). INTECH free online publication, Croatia, pp 3-31, 2012.

[13] Adjei-Nsiah S, Kuyper TW, Leeuwis C, Abekoe MK, Giller KE. Evaluating sustainable and profitable cropping sequences with cassava and four legume crops: effects on soil fertility and maize yields in the forest/savannah transitional agroecological zone of Ghana. Field Crop Res. 103, 87-97, 2007.

[14] Saragoni H, Olivier R, Poss R. Dynamique et lixiviation des éléments minéraux. Agron. Trop. 45 : 259-273, 1991.

[15] Louette D. Synthese des travaux de recherche sur la fertilité des terres de barre au Bénin et au Togo. CIRAD-DSA, 34p. Montpellier, France, 1988.

[16] Tossah BK. Influence of soil properties and organic inputs on phosphorus cycling in herbaceous legume-based cropping systems in the West African derived savanna. Ph.D. Thesis No. 428, K.U. Leuven, Belgium, 2000.

[17] Sogbedji JM. Maize nitrogen utilization and nitrate leaching modeling in Togo and New York. Ph.D. Thesis, Cornell University, New York, USA, 1999.

[18] van Es HM, van Es CL. Spatial nature of randomization and its effect on the outcome of field experiments. Agron. J. 85: 420-428, 1993.

[19] van Es HM, Gomes C, Sellmann M, van Es CL. Spatiallybalanced designs for experiments on autocorrelated fields. In: 2004 Proc. Am. Statistical Assoc., Statistics \& the Environment Section [CDROM], Alexandria, VA, 2004.

[20] IITA (International Institute for Tropical Agriculture). Automated and Semi-automated Methods for soil and plant analysis. IITA, Ibadan, Nigeria, 2014.

[21] Mathieu C, Pieltain F. Analyse physique des sols : méthodes choisies. Lavoisier, Paris, 1998.

[22] Whalen, JK, Hu Q, Liu A. Compost applications increase water-stable aggrgates in conventional and no-tillage systems. Soil Science Society of America Journal, 67, 1842 - 1847, 2003.

[23] SAS Institute. Base SAS 9.4 Procedures Guide. SAS Institute, Cary, NC, 2014.
[24] Sogbedji JM, van Es HM, Tamelokpo FA. Optimizing N fertilizer use for maize on ferralsols in Western Africa. Revue Togolaise des Sciences. (2) 2-18, 2006.

[25] Traoré K, Bado BV, Hien V. Effet du mucuna sur la productivité du maïs et du coton. INERA, Bobo Dioulasso, Burkina Faso, 1999.

[26] Galiba M, Vissoh P, Dagbenonbakin G, Fagbahon F. 1998. Réactions et craintes des paysans à la vulgarisation du pois mascate (Mucuna pruriens var. utilis). pp 55-65 In: D. Buckles, et al. (eds.) Cover crops in West Africa contributing to sustainable agriculture. IDRC, Ottawa, Canada; IITA, Ibadan, Nigeria; Sasakawa Global 2000, Cotonou, Bénin.

[27] Lamboni D. Effet de l'amélioration par le mucuna sur l'efficacité des engrais azotés et phosphatés sur le rendement en grain du maïs : Cas de l'association maïs-mucuna dans la Région Maritime. Mémoire d'Ingénieur Agronome, Université du Bénin, Lomé, Togo, 106p, 2000.

[28] Ngome, AFE, Becker M, Mtei KM. Leguminous cover crops differentially affect maize yields in three contrasting soil types of Kakamega, Western Kenya. Journal of Agricultural and Rural Development in the Tropics and Subtropics. Vol. 112 No. 1(2011)1-10, 2011.

[29] Chabi-Olaye A, Nolte C, Schulthess F, Borgemeister C. Effects of grain legumes and cover crops on maize yield and plant damage by Busseola fusca (Fuller) (Lepidoptera: Noctuidae) in the humid forest of southern Cameroon. Agriculture, Ecosystems and Environment. 108(1) 17-28, 2005.

[30] Hulugalle NR. Effect of cover crop on soil physical and chemical properties of an alfisol in the Sudan savannah of Burkina Faso. Arid Soil Research and Rehabilitation. Vol. 2 (4)251-267, 2009.

[31] Adediran JA, Akande MO, Oluwatoyinbo FI. Effect of mucuna intercropped with maize on soil fertility and yield of maize. Ghana Jnl Agric. Sci. 37, 15-22, 2003.

[32] Omotayo OE, Chukwuka KS. Soil fertility restoration techniques in sub-Saharan Africa using organic resources. African Journal of Agricultural Research Vol. 4 (3), pp. 144$150,2009$.

[33] Taboada-Castr MM, Alves MC, Whalen J. Effect of tillage practices on aggregate size distribution in a Latossolo Vermelho (Oxisol) of Sp-Brazil. 13th International Soil Conservation Organisation Conference - Brisbane, July 2004.

[34] Ouattara K, Ouattara B, Nyberg G, Sedogo MP, Malmer A. Effects of ploughing frequency and compost on soil aggregate stability in a cotton-maize (Gossypium hirsutum-Zea mays) rotation in Burkina Faso. Soil Use and Management. 24, 1928, 2008. 